\title{
EDITORIAL
}

\section{Allogeneic haematopoietic stem cell transplantation for severe autoimmune diseases: great expectations but controversial evidence}

\author{
Bone Marrow Transplantation (2006) 38, 1-4. \\ doi:10.1038/sj.bmt.1705394
}

Autoimmune diseases (ADs) have been defined as a 'fascinating but still poorly understood group of diseases', which pose 'some of the most baffling scientific questions and daunting clinical challenges in internal medicine'. ${ }^{1}$ This statement still holds true, and it is generally recognized that ADs result from three interacting components: genetic, environmental and regulatory. ${ }^{2,3}$ In spite of this complexity and of considerable overlap, there is a tendency to distinguish ADs with an impaired immune system, also known as primary ADs, from those that are predominantly antigen driven. ${ }^{4}$ There is no better demonstration of the latter than the clinical studies that have shown the disappearance of autoantibodies (antithyroid, anti-tissue transglutaminase) following removal of the antigens (by thyroidectomy or by gluten-free diet, respectively). ${ }^{5,6}$ The proposal that transplantation with genetically engineered stem cells with the culprit antigen expressed by donorantigen-presenting cells in the thymus might result in immunological tolerance ${ }^{7}$ is in accordance with this current line of thought, which includes the Matzinger 'danger' model of autoimmunity. ${ }^{8,9} \mathrm{~A}$ different outlook is apparent for the primary ADs, in which profound abnormalities of the patients' immune system are in the foreground. Systemic lupus erythematosus (SLE) is the most prominent example of this type of pathogenetic mechanism, where the intrinsic tendency of $\mathrm{B}$ cells to respond excessively to immune stimulation is thought to be an essential feature of the disease, ${ }^{10}$ and causes a veritable 'autoantibody explosion'. ${ }^{11}$

Following pioneering experimental studies, ${ }^{12,13}$ autologous haematopoietic stem cell transplantation (autoSCT) has now become an accepted therapeutic procedure for severe ADs, despite the paradox of trying to restore tolerance by transplanting the patients' own stem cells. Extensive reviews have been published, some very recently. ${ }^{14-17}$ Even if there is still some uncertainty as to whether genuine tolerance may be really achieved, ${ }^{18,19}$ disease progression has been clearly shown to be delayed, especially following high-dose conditioning, albeit with the drawback of some transplant-related mortality (TRM). ${ }^{20}$ In order to reduce TRM to a minimum, more specifically lymphoablative conditioning regimens have been proposed. ${ }^{21}$ However, in spite of its accepted therapeutic significance, of the long-term remissions that can be sometimes achieved ${ }^{22,23}$ and of the capacity to respond to treatment again in previously refractory patients, no authentic cure can be expected. ${ }^{24-26}$ This is well exemplified by two patients with coexisting $\mathrm{AD}$ and malignant disease in whom autoSCT was followed by cure of the malignancy but not of the AD. ${ }^{27,28}$

The suggestion that allogeneic SCT (alloSCT) might have a more far-reaching effect was based originally on the favourable results in patients with AD coexisting with other diseases. ${ }^{29}$ A position paper was published recently that stated that alloSCT was expected to be highly effective for inducing sustained remissions or 'cure' of autoimmune diseases. ${ }^{30}$ A series of mechanisms were considered, including immunomodulation, tolerization by regulatory $\mathrm{T}$ cells and, most importantly, immune-mediated destruction of autoreactive cells. ${ }^{31}$ By analogy with the multiple clinical diversifications of immune cellular immunotherapy, ${ }^{32}$ this last effect was defined as graft-versus-autoimmunity (GVA) ${ }^{33,34}$ As with the more common and better known graft-versus-leukaemia effect, also GVA was found to be more robust when associated with graft-versus-host disease. ${ }^{35,36}$

On the other hand, it has been claimed that mixed chimaerism might be sufficient to keep under control the autoreactive mechanisms. This is certainly true in experimental autoimmunity, where it has been investigated and confirmed in numerous laboratories. ${ }^{37-39}$ However, the situation is far from being so straightforward in clinical medicine. Here, along with cases in which post-alloSCT mixed chimaerism proved effective in controlling the $\mathrm{AD},{ }^{40,41}$ there are others in which it was accompanied by relapse of $\mathrm{AD}{ }^{42,43}$ The concept that complete remission of AD depends upon full donor chimaerism has been validated by the favourable effects of donor lymphocyte transfusions (DLI) post transplant, designed to obtain full donor chimaerism. ${ }^{44}{ }^{46}$ Unfortunately, there are also cases in which the AD relapsed in spite of full donor chimaerism. The first is the now famous patient with rheumatoid arthritis (RA) in Toronto, who underwent alloSCT from her HLA-identical brother because of gold-induced aplasia, and then relapsed with RA 2 years later despite continuing full donor chimaerism. ${ }^{47}$ Chimaerism was assessed by cytogenetics and by tandem repeat-based DNA typing. In the other case of two concomitant diseases, a patient with seropositive RA received a nonmyeloablative allogeneic peripheral blood SCT because of multiple myeloma, achieved complete remission of both diseases with disappearance of paraprotein and rheumatoid factor (RF), but relapsed with RA 10 months after transplantation. ${ }^{48}$ It may be noted that the HLA-identical brother donor had weak RF positivity. In addition, peripheral blood transplants are devoid of mesenchymal cells, which may have a beneficial effect on AD. ${ }^{49}$ Perhaps the most informative case of AD 
relapsing in spite of full donor chimaerism has been recently observed in Genoa. This was a patient with refractory Evans syndrome who had been transplanted with bone marrow from his HLA-identical sister in 2000, and had received five DLIs in order to achieve full donor chimaerism and complete clinical and haematologic remission. ${ }^{50}$ However, he had a catastrophic relapse 5 years later. Full donor chimaerism persisted, and the supernatants of ex vivo-cultured and expanded B lymphocytes contained immunoglobulin ( $\operatorname{Ig}) \mathrm{G}$ and $\operatorname{IgM}$ that did not react with the panel of erythrocytes against which the antibodies eluted from the patient's Coombs-positive red cells ${ }^{51}$ were directed.

The immunologic interpretation of these almost paradoxical relapses in patients with full post transplant donor chimaerism is still obscure. T cells appear to be involved in the RA relapses, and it has been hypothesized that residual recipient cells could sensitize HLA-identical donor $\mathrm{T}$ cells to perpetuate the immunologic imbalance underlying RA. ${ }^{48}$ However, in a typical B-mediated disease such as Evans syndrome, a more appropriate interpretation could originate from the notion of long-lived recipient plasma cells, the contribution of which to long-standing, refractory humoral autoimmunity has been shown recently. ${ }^{52,53}$ Shortlived plasma blasts have been shown to become long-lived plasma cells, occupying postulated survival niches. In NZB/ W mice, a typical model for SLE, long-lived autoreactive plasma cells have been demonstrated in the bone marrow and in the spleen. ${ }^{54}$ However, it is a classical notion that they can be eradicated following alloSCT, a finding that was pivotal for the development of stem cell therapy for autoimmunity in humans. ${ }^{55}$ An array of cytokines are necessary for plasma cell survival, such as the well-known interleukin-6 and also BAFF and APRIL, ${ }^{56}$ but the most relevant for plasma cell maintenance has been shown to be Blimp-1. ${ }^{57}$ Allotransplantation in lupus mice has been shown to overcome the disease, ${ }^{12-14}$ but, in the light of these observations, one could suspect that a greater degree of refractoriness may be found in human patients with systemic autoimmune diseases than suspected previously.

Single case reports, no matter how carefully studied, cannot provide the final answer but still they should not be ignored. If it were confirmed that minimal residual autoimmune disease is capable of surviving the GVA effects of alloSCT, then the possible advantage of alloSCT over the safer, although perhaps immunologically less appealing, autoSCT procedure would inevitably be reduced.

AM Marmont Division of Haematology and Stem Cell Transplantation Centre, S Martino's Hospital, Genoa, Italy E-mail: alberto.marmont@hsanmartino.it

\section{References}

1 Davidson A, Diamond B. Autoimmune diseases. $N$ Engl J Med 2001; 345: 340-350.

2 Ermann J, Fathman CG. Autoimmune diseases: genes, bugs and failed regulation. Nat Immunol 2002; 2: 759-766.
3 Fathman CG, Soares L, Chan SM, Utz PJ. An array of possibilities for the study of autoimmunity. Nature 2005; $\mathbf{4 3 5}$ : 605-611.

4 Amital H, Shoenfeld Y. Autoimmunity and autoimmune diseases such as systemic lupus erythematosus. In: Lahita RG (ed). Systemic Lupus Erythematosus, 4th edn. Elsevier: Amsterdam-Tokyo, 2004, pp 3-27.

5 Chiovato L, Latrofa F, Braverman LE, Pacioni F, Capezzone M, Masserini L et al. Disappearance of humoral thyroid autoimmunity after complete removal of thyroid antigens. Ann Intern Med 2003; 139: 346-351.

6 Ventura A, Not T, Tommasini A, Marzari R, Sblattero D. Autoantibodies as predictors of disease. Lancet 2004; 364 : 1403.

7 Alderuccio F, Murphy K, Toh B-H. Stem cells engineered to express self-antigen to treat autoimmunity. Trends Immunol 2003; 24: 176-180.

8 Matzinger P. Tolerance, danger and the extended family. Annu Rev Immunol 1994; 12: 991-1045.

9 Reines BP. Bystanders or bad seeds? Many autoimmune-target cells may be transforming in cancer and signaling 'danger' to the immune system. Autoimmunity 2001; 33: 121-134.

10 Lipsky PE. Systemic lupus erythematosus: an autoimmune disease of B cell hyperreactivity. Nat Immunol 2002; 2: 764-766.

11 Sherer Y, Gorstein A, Fritzler M, Shoenfeld Y. Autoantibody explosion in systemic lupus erythematosus: more than 100 different antibodies found in SLE patients. Semin Arthritis Rheum 2004; 34: 501-537.

12 Ikehara S. Treatment of autoimmune disease by hematopoietic stem cell transplantation. Exp Hematol 2001; 29: 661-669.

13 van Bekkum DW. Preclinical experiments. Best Pract Res Clin Haematol 2004; 17: 201-222.

14 Burt RK, Marmont AM. Stem Cell Therapy for Autoimmune Disease. Landes Bioscience: Georgetown, TX, USA, 2004.

15 Burt RK, Slavin S, Burns W, Marmont AM. Induction of tolerance in autoimmune diseases by hematopoietic stem cell transplantation. Getting closer to a cure? Blood 2002; 99: 768-784.

16 Hough RE, Snowden JA, Wulffraat NM. Haematopoietic stem cell transplantation in autoimmune diseases: a European perspective. Br J Haematol 2005; 128: 432-459.

17 Tyndall A, Saccardi R. Haematopoietic stem cell transplantation in the treatment of severe autoimmune disease: results from phase I/II studies, prospective randomized trials and future directions. Clin Exp Immunol 2005; 141: 1-9.

18 Sun W, Popat U, Hutton G, Ying CQ, Zhang J, Krance R et al. Characteristics of T-cell receptor repertoire and myelinreactive $\mathrm{T}$ cells reconstituted from autologous haematopoietic stem-cell grafts in multiple sclerosis. Brain 2004; 127: 996-1008

19 Muraro P, Douek DK, Packer A, Chung K, Guenaga FJ, Cassini-Ingoni $\mathrm{R}$ et al. Thymic output generates a new and diverse TCR repertoire after autologous stem cell transplantation in multiple sclerosis patients. $J$ Exp Med 2005; 201: $805-816$

20 Gratwohl A, Passweg J, Bocelli-Tyndall C, Fassas A, van Laar $\mathrm{JM}$, Farge D et al. Autologous hematopoietic stem cell transplantation for autoimmune diseases. Bone Marrow Transplant 2005; 35: 869-879.

21 Burt RK, Oyama Y, Marmont AM, Slavin S, Arnold R, Hiepe F et al. Randomized controlled trials of autologous stem cell transplantation for autoimmune diseases: the evolution from myeloablative to lymphoablative regimens. Arthritis Rheum 2006 (in press).

22 Burt RK, Traynor A, Statkute L, Barr WG, Rosa R, Schroeder $\mathbf{J}$ et al. Nonmyeloablative hematopoietic stem cell 
transplantation for systemic lupus erythematosus. JAMA 2006; 295: 527-535.

23 Marmont AM, Gualandi F, van Lint MT, Guastoni C, Bacigalupo A. Long-term complete remission of severe nephrotic syndrome secondary to diffuse global (IV-6) lupus nephritis following autologous, haematopoietic peripheral stem (CD34+) transplantation. Lupus 2006; 15: 44-46.

24 Brenner MK. Haematopoietic stem cell transplantation for autoimmune disease: limits and future potential. Best Pract Res Clin Haematol 2004; 17: 359-374.

25 Petri M, Brodsky R. High-dose cyclophosphamide and stem cell transplantation for refractory systemic lupus erythematosus. JAMA 2006; 295: 559-560.

26 Euler HH, Marmont AM, Bacigalupo A, Fastenrath S, Dreger $\mathrm{P}$, Hoffknecht $\mathrm{M}$ et al. Early recurrence or persistence of autoimmune diseases after unmanipulated autologous stem cell transplantation. Blood 1996; 88: 3621-3625.

27 Rosler W, Wanger B, Repp R, Kalden JR, Gramatzki M. Autologous PBSCT in a patient with lymphoma and Sjogren syndrome. Complete remission of lymphoma without control of the autoimmune disease. Bone Marrow Transplant 1998; 22: 211-213.

28 Ferraccioli G, Damato R, De Vita S, Fanin R, Damiani D, Baccarani M. Hematopoietic stem cell transplantation (HSCT) in a patient with Sjogren's syndrome and lung malt lymphoma cured lymphoma not the autoimmune disease. Ann Rheum Dis 2001; 60: 174-176.

29 Marmont AM. Coincidental autoimmune diseases in patients transplanted for conventional indications. Best Pract Res Clin Haematol 2004; 17: 223-232.

30 Griffith LM, Pavletic SZ, Tyndall A, Bredeson CN, Bowen JD, Childs RW et al. Feasability of allogeneic hematopoietic stem cell transplantation for autoimmune disease: position statement from a National Institute of Allergy and Infectious Diseases and National Cancer-Institute-sponsored International Workshop, Bethesda, MD, March 12 and 13, 2005. Biol Blood Marrow Transplant 2005; 11: 862-870.

31 Sykes M, Nikolic B. Treatment of severe autoimmune disease by stem-cell transplantation. Nature 2005; 435: 620-627.

32 Appelbaum FR. Hematopoietic stem cell transplantation as immunotherapy. Nat Med 2001; 41: 385-389.

33 Slavin S, Nagler A, Varadi G, Or R. Graft vs autoimmunity following allogeneic nonmyeloablative blood stem cell transplantation in a patient with chronic myelogenous leukemia and severe systemic psoriasis and psoriatic polyarthritis. Exp Hematol 2000; 28: 853-857.

34 Marmont AM. Is there any evidence of a graft-versusautoimmunity effect in allogeneic transplantation? Blood Marrow Transplant Rev 2004; 4: 11.

35 Hinterberger W, Hinterberger-Fischer M, Marmont AM. Clinically demonstrable anti-autoimmunity mediated by allogeneic immune cells favorably affects outcome after stem cell transplantation in human autoimmune diseases. Bone Marrow Transplant 2002; 30: 753-759.

36 Oyama Y, Papadopoulos EB, Mirando M, Traynor AE, Burt RK. Allogeneic stem cell transplantation for Evans syndrome. Bone Marrow Transplant 2001; 28: 903-905.

$37 \mathrm{Li} \mathrm{H}$, Kaufman CL, Boggs SS, Johnson PC, Patrene KD, Ildstad ST. Mixed allogeneic chimerism induced by a sublethal approach prevents autoimmune diabetes and reverses insulitis in nonobese diabetic (NOD) mice. J Immunol 1996; 156: 380-387.

38 Seung E, Iwakoshi N, Woda BA, Markees TG, Mordes JP, Rossini AA et al. Allogeneic hematopoietic chimerism in mice treated with sublethal myeloablation and anti-CD154 antibody: absence of graft-versus-host disease, induction of skin allograft tolerance, and prevention of recurrent auto- immunity in islet-allografted NOD/Lt mice. Blood 2000; 95: 2175-2182.

39 Good RA, Wang BY, El-Badri NS, Steele A, Verjee T. Mixed bone marrow or mixed stem cell transplantation for prevention or treatment of lupus-like disease in mice. Exp Nephrol 2002; 10: $408-420$.

40 Chakrabarti S, Handa SK, Byron RJ, Griffiths MJ, Milligan DW. Will mixed chimerism cure autoimmune diseases after a nonmyeloablative stem cell transplant? Transplantation 2001; 72: $340-342$.

41 Burt RK, Oyama Y, Verda L, Onigley K, Brush M, Yaung K et al. Induction of remission of severe and refractory rheumatoid arthritis by allogeneic mixed chimerism. Arthritis Rheum 2004; 50: 2466-2470.

42 Kojima R, Kami M, Kim S-W, Murashige N, Kishi Y, Hori A et al. Induction of graft-versus-autoimmune (GVA) disease effect against refractory psoriasis by complete donor-type chimerism, and graft-versus-host disease after allogeneic hematopoietic system cell transplantation. Bone Marrow Transplant 2003; 32: 439-442.

43 Seifert B, Passweg JK, Heim D, Rovo A, Meyer-Monard S, Bushner $\mathrm{S}$ et al. Complete remission of alopecia universalis after allogeneic hematopoietic stem cell transplantation. Transplantation 2005; 105: 426-427.

44 Marmont AM, Gualandi F, van Lint MT, Bacigalupo A. Refractory Evans syndrome treated with allogeneic SCT followed by DLI. Demonstration of a graft-versus autoimmunity effect. Bone Marrow Transplant 2003; 31: 399-401.

45 Musso M, Porretto F, Crescimanno A, Polizzi V, Scalone R. Donor lymphocyte infusions for refractory pure red cell aplasia relapsing after both autologous and allogeneic peripheral stem cell transplantation. Bone Marrow Transplant 2004; 33: 769-771.

46 Hayden PJ, Crampe M, Lawler M, Conneally E, McCann SR, Vandenberghe E et al. Use of DLI to achieve complete donor chimerism in a patient receiving systemic immunosuppression for refractory AIHA post-NST. Bone Marrow Transplant 2005; 36: 735-736.

47 McKendry RJ, Huebsch L, Leclair B. Progression of rheumatoid arthritis following bone marrow transplantation. A case report with a 13-year follow-up. Arthritis Rheum 1996; 39: $1246-1253$

48 Tapprich C, Feuk R, Schneider P, Bernhardt A, Haas R, Kobbe G. Early recurrence of rheumatoid arthritis after nonmyeloablative allogeneic blood stem cell transplantation in a patient with multiple myeloma. Bone Marrow Transplant 2003; 32: 629-631.

49 El-Badri NS, Maheshwari A, Sanberg PR. Mesenchymal stem cells in autoimmune disease. Stem Cell Dev 2004; 13: 463-472.

50 Marmont AM, Gualandi F, van Lint MT, Bacigalupo A. Refractory Evans syndrome treated with allogeneic SCT followed by DLI. Demonstration of a graft-versus-autoimmunity effect. Bone Marrow Transplant 2003; 31: 399-402.

51 Marmont AM, Gualandi F, Occhini D, Morandi F, Ferretti E, Pezzolo A et al. Catastrophic relapse of Evans syndrome five years after allogeneic BMT notwithstanding full donor chimerism Terminal haemolytic-uremic syndrome. Autoimmunity (in press).

52 Hoyer BE, Manz RA, Radbruch A, Hiepe F. Long-lived plasma cells and their contribution to autoimmunity. Ann $N Y$ Acad Sci 2005; 1050: 124-133.

53 Manz RA, Hanser AE, Hiepe F, Radbruch A. Maintenance of serum antibody levels. Annu Rev Immunol 2005; 23: 367-386.

54 Hoyer B, Moser K, Hanser AE, Peddinghaus A, Voigt C, Eilat $\mathrm{D}$ et al. Short-lived plasma blasts and long-lived plasma cells contribute to chronic humoral autoimmunity in NZB/W mice. $J$ Exp Med 2004; 199: 1577-1584. 
55 Marmont AM. Historical perspective and rationale of HSCT for autoimmune diseases. In: Burt RK, Marmont AM (eds) Stem Cell Therapy for Autoimmune Diseases. Landes Bioscience: Georgetown, USA, 2004.

56 O'Connor BP, Raman VS, Erickson LD, Cook WJ, Weaver LK, Ahonen $\mathrm{C}$ et al. BCMA is essential for the survival of

long-lived bone marrow plasma cells. $J$ Exp Med 2004; 199: 91-98.

57 Shapiro-Shelef M, Lin K-I, Savitsky D, Liao J, Calame K. Blimp-1 is required for maintenance of longlived plasma cells in the bone marrow. J Exp Med 2005; 202: 1471-1476. 